Reprod. Nutr. Dévelop. 1980, 20 (1 A), 77-92.

\title{
Effects of fasting on blood composition and nitrogen losses in the adult sheep depending on previous diet and body weight
}

\author{
par J. CI. BOUCHAT, Françoise DOIZÉ, R. PAQUAY \\ with the technical assistance of Marie-Antoinette BOUCKOMS and D. CLOOSTERMANS \\ Laboratoire de Physiologie animale, Facultés Universitaires \\ Notre-Dame de la Paix, B-5000 Namur, Belgium.
}

\begin{abstract}
Summary. In order to study the profiles of blood composition and nitrogen losses during fasting, groups of adult sheep that had previously received diets with variable intake levels were fasted during 8-day periods. A decrease in blood ketone concentration was observed during the first day, followed by a strong increase after 36 to $48 \mathrm{hrs}$. After 5 to 6 days, this concentration seemed to stabilize in the previously overfed animals, while it continued to increase for a week in the previously underfed sheep. The $\beta$-hydroxybutyrate $(B H B) / a c e t o a c e t a t e(A A)$ ratio decreased during fasting. No orderly pattern of glycemia was obtained; it seemed to decrease after $36 \mathrm{hrs}$ and then increase after 5 to 6 days. The previous level of food intake did not affect the pattern. Fasting induced a higher rate of cholesterol esterification, and from the end of the first day, there was a rapid increment in the plasma free fatty acid (FFA) content which apparently stabilized after 5 to 6 days. The distribution of fatty acids in the different lipids also varied, showing principally an increase of oleic acid balanced by a decrease of the saturated fatty acids in the FFA and of the other unsaturated fatty acids in the phospholipids and cholesteryl esters. Some of these modification in the blood lipids depended on previous dietary conditions. The fecal nitrogen losses decreased quickly during the fasting period, whereas the urinary losses remained high during the first days, particularly in the overfed animals. These sheep lost 3 to 4 p. 100 of their total body protein in 4 days, demonstrating that there was a labile fraction in the total protein reserves which was rapidly available during food restriction. The role of the ketone bodies and the protein reserves in meeting energy needs and in maintaining glycemia during fasting have been discussed.
\end{abstract}

\section{Introduction.}

Depending on food conditions, animals have the ability to accumulate more or less lipid reserves according to the level of voluntary food intake. Food restriction or fasting entails mobilization of the fat reserves, and consequently affects blood composition and the urinary loss of different substances.

In sheep, fasting induces a strong increase in the concentration of blood ketone bodies (Baetz, 1976 ; Demigné and Rémésy, 1977) with a lower rate of $\beta$-hydroxybutyrate (Annison ef al., 1967 ; Katz and Bergman, 1969). The results obtained on 
glycemia are contradictory. There is a rapid increment in plasma free fatty acid content (Günzel and Giesecke, 1974 ; Kaufman and Bergman, 1971 ; Thompson, Gardner and Bell, 1975 ; Thye, Warner and Miller, 1970). Other data on blood lipid composition in fattening sheep are rare. Leat and Ford (1966) noted a higher stearic and palmitic acid entry rate into the plasma in pregnant and non-pregnant ewes.

It is likely that lipid mobilization rate during fasting and the effect on the blood composition are influenced by the level of the lipid reserves which depends on previous feeding conditions; however, only a few data are available. Bowden (1973) found no influence of previous intake level on the rate of ketone bodies, glucose or free fatty acids produced by lactating cows during fasting.

The assays were realized in order to determine the variation of some blood substances of carbohydrate and lipid metabolism in adult sheep and to compare their profiles with urinary nitrogen losses. A second objective was to ascertain the effects of previous food conditions and thus of the level of lipid reserves on these parameters. The results are reported in this paper.

\section{Materials and methods.}

Three tests were carried out using 11 adult Suffolk sheep. During a preliminary test two groups of 2 animals each, previously fed ad libitum (overfed) or a limited diet (underfed) during 3 to 4 months, were fasted for 4 days. Blood, urine and faeces were sampled regularly. Only a few parameters were studied (blood ketone bodies and faecal and urinary nitrogen), and since the results were comparable to those obtained in other tests, they will not be reported. The design of the other tests (tests 1 and 2) is shown in table 1.

TABLE 1

Summary of the experimental design : for details, see the text

\begin{tabular}{|c|c|c|c|c|c|c|c|c|c|}
\hline \multirow{2}{*}{$\begin{array}{l}\text { No } \\
\text { of } \\
\text { test }\end{array}$} & \multirow[b]{2}{*}{ Treatment } & \multirow[b]{2}{*}{ Sheep } & \multirow[b]{2}{*}{ Sex } & \multirow[b]{2}{*}{ Age } & \multirow{2}{*}{$\begin{array}{l}\text { Weight } \\
\text { before } \\
\text { fasting }\end{array}$} & \multirow[b]{2}{*}{ Dates } & \multicolumn{3}{|c|}{ Feed $(\mathrm{kg})$} \\
\hline & & & & & & & $\begin{array}{l}\text { Pasture } \\
\text { hay }\end{array}$ & $\begin{array}{l}\text { Alfalfa } \\
\text { pellets }\end{array}$ & Concentrate \\
\hline \multirow{4}{*}{1} & \multirow{2}{*}{ Overfed } & \multirow{2}{*}{ A } & \multirow{2}{*}{$\sigma$} & \multirow{2}{*}{2} & \multirow{2}{*}{88} & $17.12 .76-17.04 .77$ & 0.5 & & ad libitum (a) \\
\hline & & & & & & $18.04 .77-25.04 .77$ & & fasting & \\
\hline & \multirow{2}{*}{ Underfed } & B & 3 & 4 & 60 & $17.12 .76-17.04 .77$ & 0.5 & & $0.3(b)$ \\
\hline & & c & q & 2 & 44 & 18.04 .77 & & fasting & \\
\hline \multirow{4}{*}{2} & \multirow{2}{*}{ Control } & D & $q$ & 3 & 58 & $28.04 .78-11.06 .78$ & 0.3 & & $0.5(c)$ \\
\hline & & $E$ & q & 2 & 51 & $12.06 .78-20.06 .78$ & & fasting & \\
\hline & \multirow{2}{*}{ Overfed } & $F$ & $q$ & 3 & 95 & $28.04 .78-11.06 .78$ & 0.3 & & od libitum (c) \\
\hline & & $G$ & q & 3 & 101 & $12.06 .78-20.06 .78$ & & fasting & \\
\hline
\end{tabular}

(a) 70 p. 100 commercial mixture, 30 p. 100 crushed oats.

(b) 50 p. 100 commercial mixture, 50 p. 100 crushed oats.

(c) 40 p. 100 dried beet pulp, 30 p. 100 dehydrated alfalfa, 30 p. 100 cereals. 
Test 1. - The first test was carried out on 3 sheep housed in metabolism cages permitting separate collection of faeces and urine. Sheep A was fed ad libitum (overfed), while sheep $B$ and $C$ were fed a limited diet (underfed) during 4 months before the fasting period. The overfed sheep received $0.5 \mathrm{~kg}$ of pasture hay (dry matter $94.7 \mathrm{p}$. 100 , mineral matter 5.6 p. 100 , protein 14.5 p. 100, crude fiber 29.8 p. 100) and a concentrate mixture (dry matter 90.8 p. 100 , mineral matter 5.4 p. 100 , protein 14.5 p. 100 , crude fiber 6.4 p. 100) ad libitum. The underfed animals received $500 \mathrm{~g}$ of the same hay and $300 \mathrm{~g}$ of a concentrate mixture composed of dry matter $91.6 \mathrm{p} .100$, mineral matter 4.3 p. 100 , protein 14.7 p. 100 and crude fiber 7.6 p. 100 . Hay was distributed at 10 a. m., concentrates at $11: 30$ a.m. and food refusals were weighed daily.

The last 2 weeks preceding the fasting period, overfed sheep A ate nearly $2.2 \mathrm{~kg}$ of the concentrate daily. During the 14 weeks this animal gained $320 \mathrm{~g}$ of weight daily, whereas the underfed sheep $B$ and $C$ lost 121 and $41 \mathrm{~g}$ per day, respectively.

On April 18, the day the test began, the daily meal was distributed at $8: 30$ a.m. and the refusals were taken away at $10 \mathrm{a} . \mathrm{m}$. ; water was always available. The first blood sample (jugular puncture, collection in heparin tubes) was taken when refusals were removed. Other blood samples were taken in the same way (every 4 hours at first and every $12 \mathrm{hrs}$ later) until $8 \mathrm{a} . \mathrm{m}$. on April 25. The concentrations of ketone bodies and free fatty acids (FFA) and the distribution of the FFA were determined in all the blood samples.

The faeces were also collected every $24 \mathrm{hrs}$ and the urine every $12 \mathrm{hrs}$ at first, then every $24 \mathrm{hrs}$ later. Sulfuric acid was placed in the urine container. The eliminated products were weighed, mixed (by power stiver for the faeces), and the samples used to determine the nitrogen content.

Test 2. - The second test was realized at the end of a long-term experiment started in August 1977 and intended to compare the control animals ( $D$ and $E$ ) to the others ( $F$ and $G$ ) which were either fed ad libitum or very underfed. During the last 6 weeks of the experiment (see table 1), sheep D and $E$ were fed $0.3 \mathrm{~kg}$ of pasture hay containing 88.6 p. 100 dry matter, 9.6 p. 100 mineral matter and 8.7 p. 100 protein, and $0.5 \mathrm{~kg}$ of concentrate containing 90.7 p. 100 dry matter, 8.5 p. 100 mineral matter and 13.2 p. 100 protein. Sheep $F$ and $G$ received $0.5 \mathrm{~kg}$ of the same hay and the concentrates ad libitum. The daily concentrate allowance was about $1.6 \mathrm{~kg}$ per sheep during the last weeks preceding the fasting period.

During the last 6 weeks, the weight of sheep $D$ remained stable between 55 and $57 \mathrm{~kg}$, while that of sheep $E$ was between 50 and $52 \mathrm{~kg}$. Sheep $F$ gained $11.3 \mathrm{~kg}$, and sheep G $9.9 \mathrm{~kg}$.

This second test, carried out in the same manner as the first one, lasted for 8 days with progressively longer intervals between blood samplings (4 hrs in the beginning, $12 \mathrm{hrs}$ at the end). Blood ketone and glucose concentrations were measured and the blood lipids were completely analyzed for lipid distribution (p. 100 of triglycerides, FFA, phospholipids, cholesterol, cholesteryl esters of total lipids), FFA content and fatty acid distribution in the lipid fractions.

Analyses. - The techniques for determining blood ketone bodies, glucose and lipids have been described in a previous paper (Doizé, Bouchat and Paquay, 1979). The dis- 
tribution of the individual acids in the triglycerides, phospholipids and cholesteryl esters was ascertained using the same technique as for FFA distribution, i.e. scraping from the thin-layer plate and gas chromatography separation.

The composition of the food was analyzed with the usual methods : oven dessiccation for dry matter content, muffle furnace incineration for ash content, Kjeldahl's method for nitrogen content and Weende's method for crude fiber content. Kjeldahl's technique was also used for determining the nitrogen content of faeces and urine.

\section{Results.}

Ketone bodies and glucose. - The results obtained for the blood ketone bodies ( $\mathrm{mg} / \mathrm{l}$ of blood) showed an identical pattern in tests 1 and 2 . The pattern of test 2 is given in figure 1.

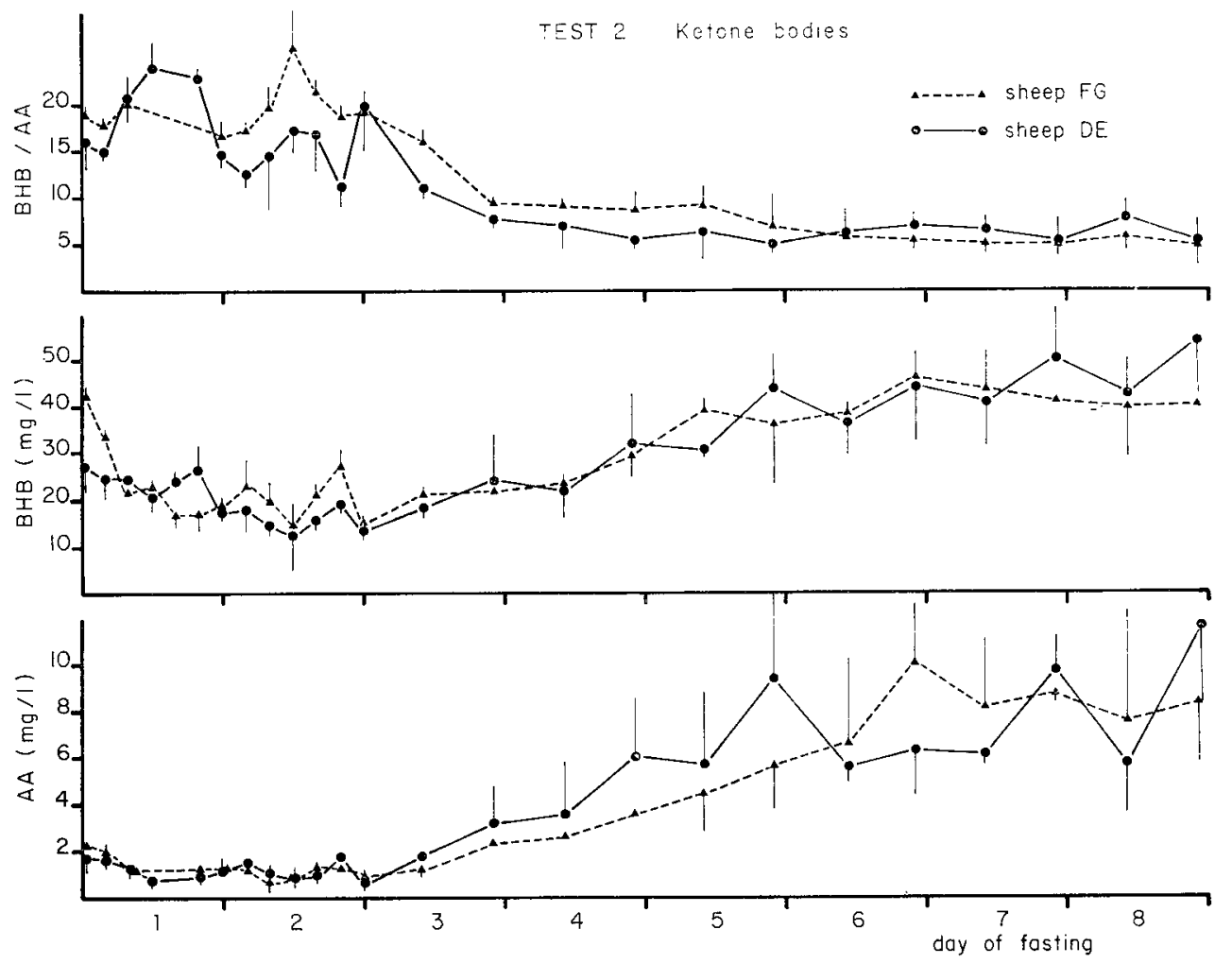

FIG. 1. - Changes in blood acetoacetate (AA) and $\beta$-hydroxybutyrate (BHB) and in $B H B / A A$ ratio of control $(D, E)$ and previously overfed $(F, G)$ sheep during test 2.

The concentration of aceloacetate (AA) and $\beta$-hydroxybutyrate (BHB) decreased during the first day, then strongly increased from 36 to $48 \mathrm{hrs}$. This augmentation was faster for $\mathrm{AA}$ than for $\mathrm{BHB}$ so that the BHB/AA ratio fluctuated between 10 and 20 at the beginning of the tests, then decreased rapidly and reached a value of 5 on the 
fourth or fifth day. It should be noted that the ketone level in the underfed ( $B, C$ : test 1) and control (D, $E$ : test 2 ) animals increased until the end of the period, whereas it stabilized in the overfed sheep (A : test $1 ; F, G$ : test 2 ) on the fifth or sixth day.

We observed no other influence (either of the level of food intake preceding the fasting period or of the fattening state) on the ketone pattern during the tests.

The values obtained for the ketone bodies during the second fasting period were examined using the analysis of variance with two factors (table 2). The results confirmed that the time of fasting had a significant effect on blood $A A, B H B$ concentration and $\mathrm{BHB} / \mathrm{AA}$ ratio.

TABLE 2

Statistical significance : kefone bodies, test two

\begin{tabular}{|c|c|c|c|}
\hline & Time of fasting & Group of animal & $\begin{array}{l}\text { Fasting-group } \\
\text { interaction }\end{array}$ \\
\hline 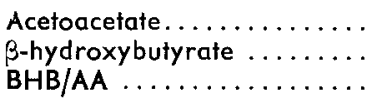 & $\begin{array}{l}* * * \\
* * * \\
* * *\end{array}$ & $\begin{array}{l}\text { NS } \\
\text { NS } \\
\text { NS }\end{array}$ & $\begin{array}{l}\text { NS } \\
\text { NS } \\
\text { NS }\end{array}$ \\
\hline
\end{tabular}

NS : not significant, *** $\mathrm{P}<0.001$.

Fasting had a much less marked influence on glycemia than on ketone bodies. The only change seemed to be a slight decrement of blood glucose content after $36 \mathrm{hrs}$ in both groups of sheep, followed by an increase at the end of the period.

The level of food intake before fasting and the fattening state did not induce differences in glycemia during fasting.

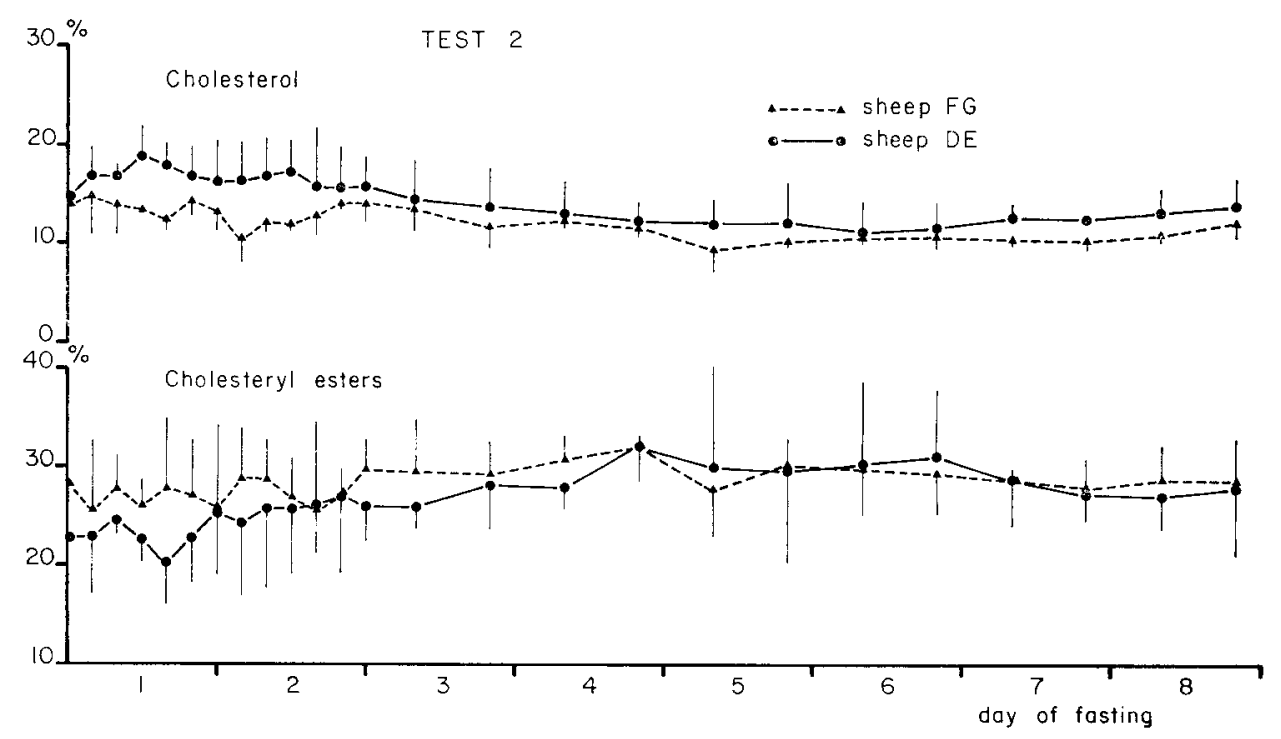

FIG. 2. - Changes in the rate (p. 100 of total blood lipids) of free cholesterol and cholesteryl esters in the blood of control (D, E) and previously overfed (F, G) sheep during test 2 . 
Plasma lipid distribution. - During fasting, the FFA represented 20 to 28 p. 100 of the total lipids, triglycerides 8 to 12 p. 100 , and phospholipids 23 to 29 p. 100 . The results and the analysis of variance, based on the time of fasting and the previous dietary conditions, showed no significant change for these components during fasting ; no influence of food intake level before the fasting period was found.

As confirmed by the analysis of variance, figure 2 shows that, in both groups, fasting induced a decrease of the cholesterol ratio in the total blood lipids, balanced by an increase of the cholesteryl ester ratio. Fasting thus caused a higher rate of cholesterol esterification.

Free fatty acid concentration. - The results obtained for plasma FFA (mg/100 cc of plasma) during the fasting periods are shown in figure 3 . Both tests present the same profile. A strong increment of the FFA concentration occurred at the end of the first day of fasting, and then stabilized on the sixth day. This was particularly evident in test 1 : the concentrations and the plasma FFA profile were the same in both groups. During test 2 , the FFA values of sheep previously fed a maintenance diet were high at the beginning of the test, then paralleled those of the overfed sheep.

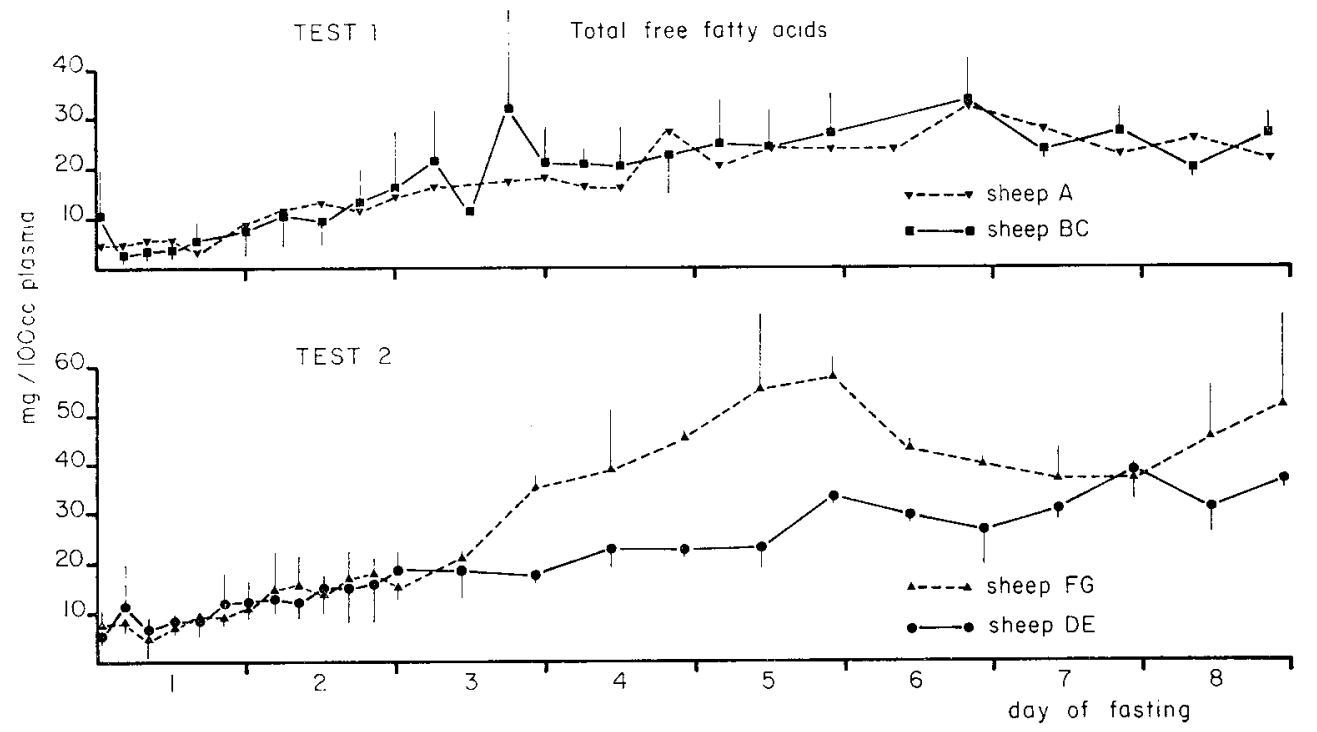

FIG. 3. - Changes in plasma free fatty acid content during tests 1 and 2 .

(--.-. previously overfed sheep, __ previously underfed or control sheep).

The analysis of variance confirmed that the time of fasting had a highly significant effect $(P<0.001)$ on plasma FFA level, whereas previous diefary conditions had no such effect on mean FFA concentration, but influenced its pattern during fasting $(P<0.01)$.

Blood lipid fatty acid distribution. - Blood lipid fatty acid distribution in test 2 and the results of the analysis of variance are found in tables 3 to 6 . Only the important modifications have been included. 


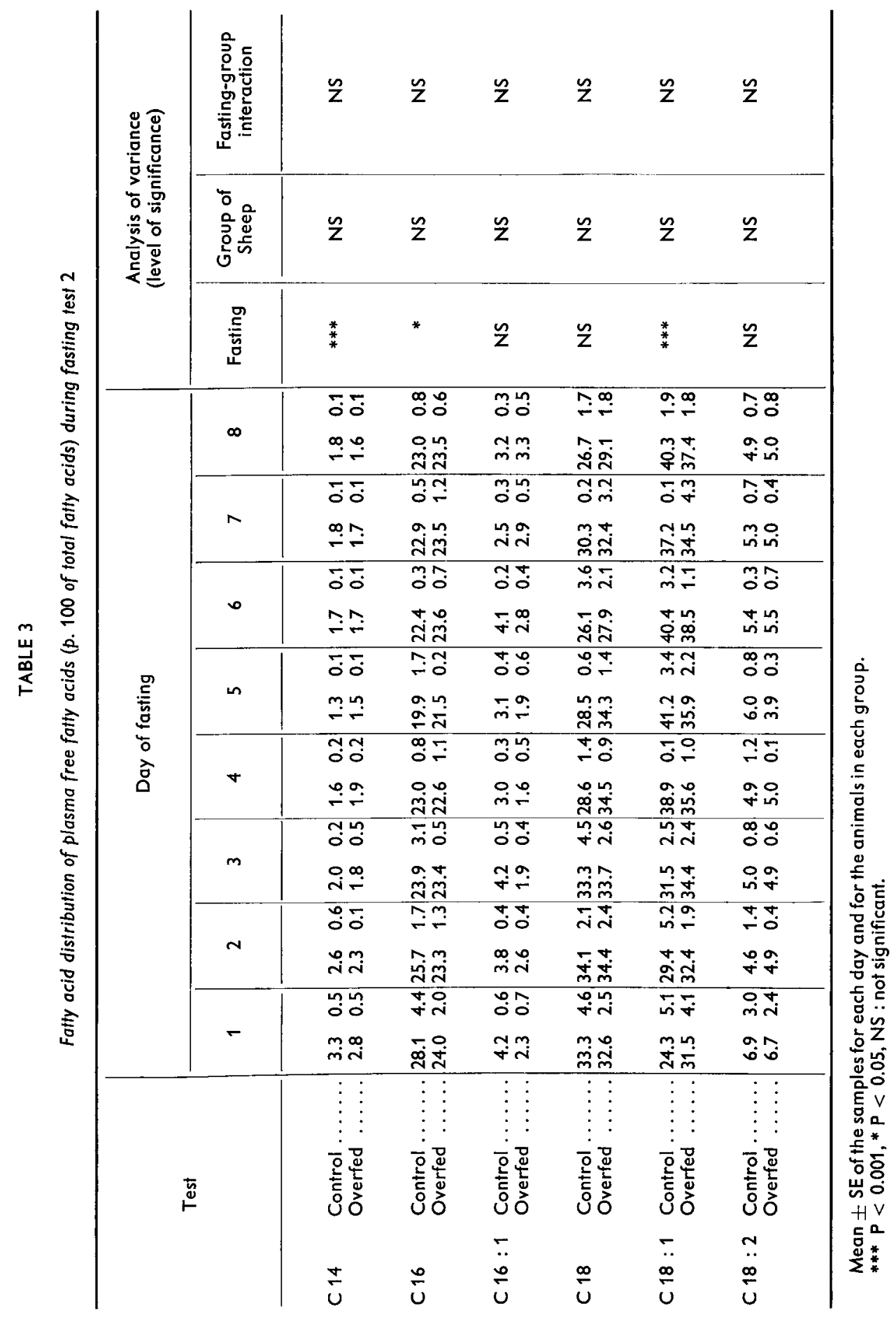


In both groups, but principally in the control animals, fasting induced a significant increment of the oleic acid rate in the FFA. The rate of myristic acid decreased in both groups and that of palmitic acid only in the control group. These variations were evident during the first 4 to 5 days, and then stabilized.

Fasting had little effect on the distribution of triglyceride fatty acids : the rate of oleic acid augmented in the overfed sheep. Contrary to oleic acid, the stearic acid-rate seemed to be higher in the control animals than in the previously overfed ones, but these differences were not significant.

The distribution of phospholipid free fatty acids, mainly that of $C 16: 0$ varied during fasting ; $C 16: 0, C 18: 0$ and $C 18: 1$ increased, and $C 18: 2$ and $C 16: 1$ decreased. The type of food previously given had no effect.

In both groups of animals, but principally in overfed sheep, fasting induced the rate of $C 18: 1$ and $C 16: 0$ in the cholesteryl esters to augment, and that of $C 16: 0$, $C 18: 2$ and $C 18: 3$ to decrease.

Nitrogen losses. - The values obtained for faecal and urinary losses during test 1 are shown on figure 4 . In all animals, fasting produced a rapid decrease of faecal nitrogen losses. On the third day, the losses were lower than $0.1 \mathrm{~g} / \mathrm{animal} / \mathrm{hr}$ and on the fifth day they decreased even more to less than $0.05 \mathrm{~g} / \mathrm{animal} / \mathrm{hr}$. Urinary nitrogen losses in previously overfed sheep were clearly higher than in the underfed ones. The first day the values were higher than $1 \mathrm{~g} / \mathrm{hr}$ in sheep A. Later, they decreased rapidly, but still exceeded $0.4 \mathrm{~g} / \mathrm{hr}$ on the fourth day, and then remained at $0.25 \mathrm{~g} / \mathrm{hr}$ until the eighth day.

During the first 4 days of fasting, sheep A lost $75.7 \mathrm{~g}$ of urinary nitrogen, that is a protein equivalent of $0.473 \mathrm{~kg}$. Body weight was $88 \mathrm{~kg}$ at the beginning of the fasting period. With a presumed ratio of 16 p. 100 body protein, the animal lost 3.36 p. 100 of its body protein in 4 days. In the preliminary test, a mean value of 3.45 p. 100 was obtained for two sheep.

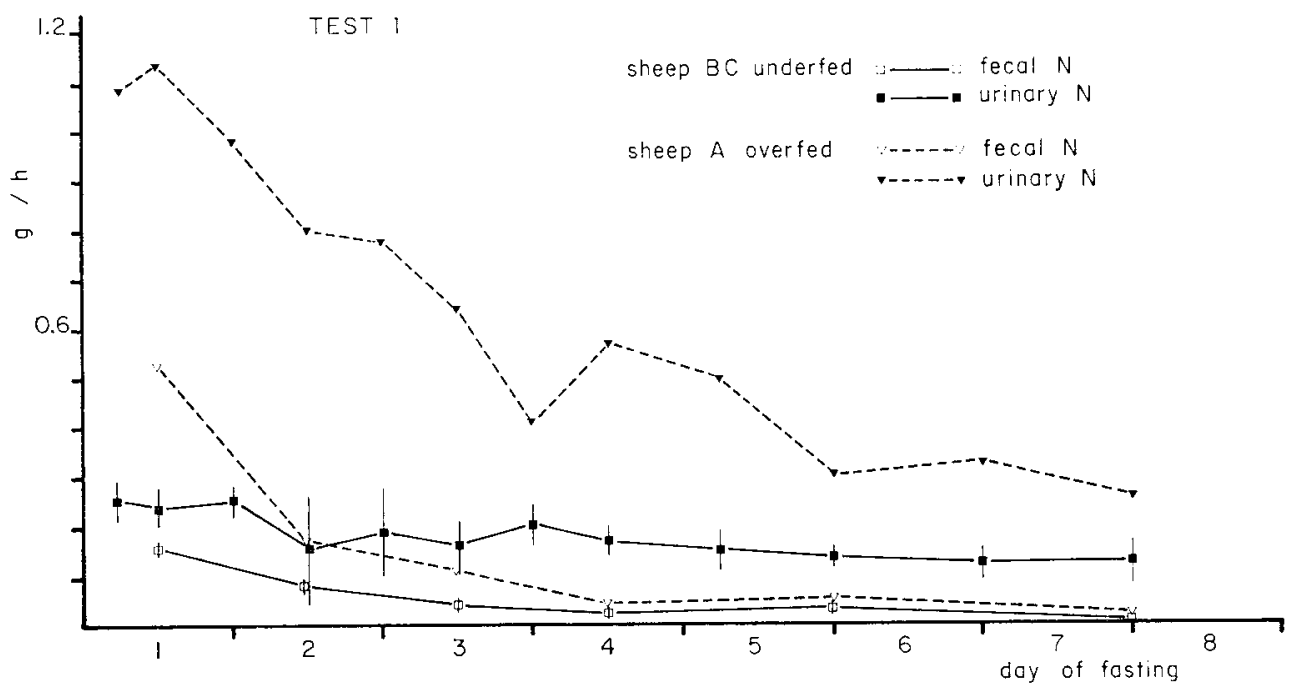

FIG. 4. - Changes in fecol and urinary nitrogen losses (g/animal/hr) of sheep during test 1. 


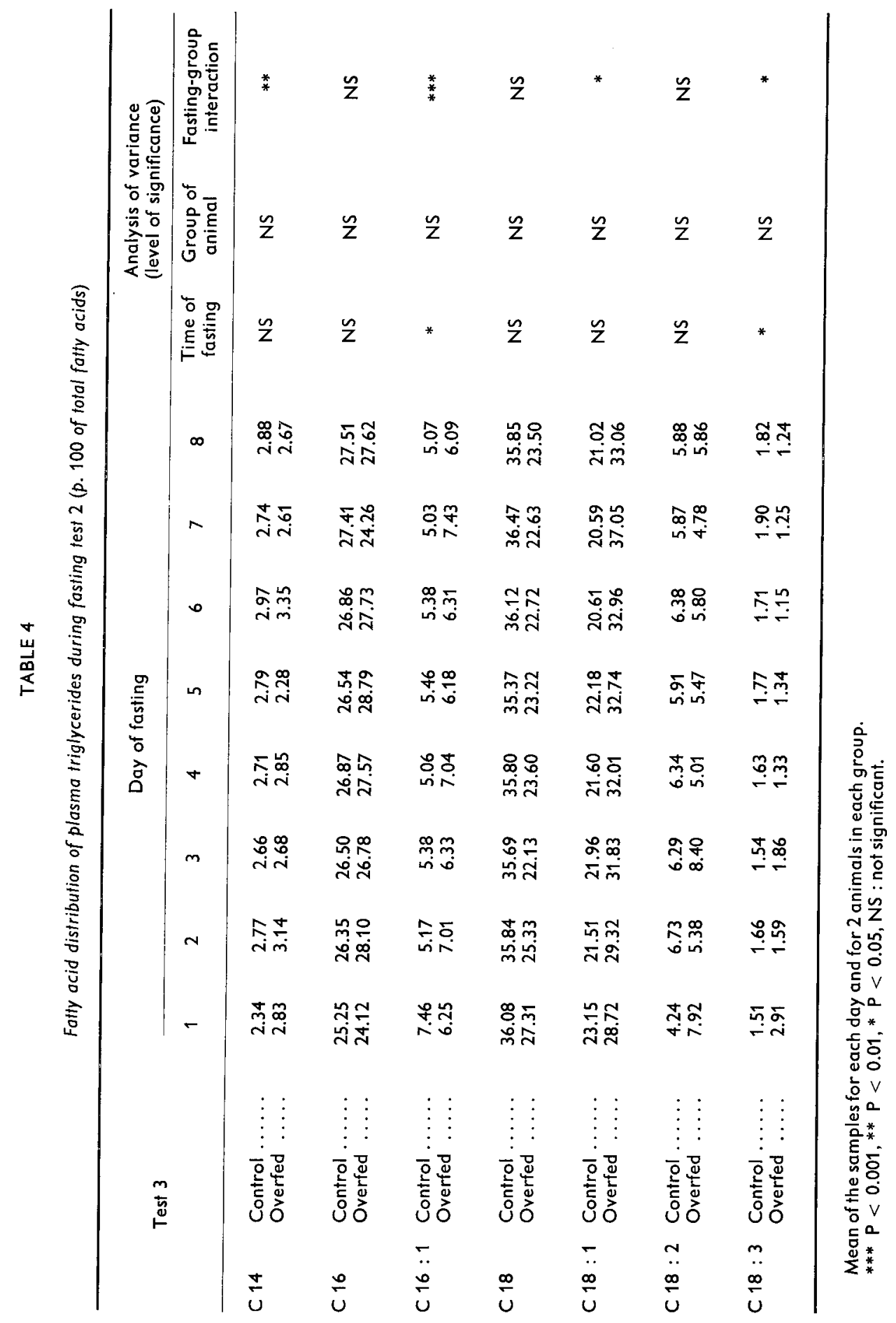




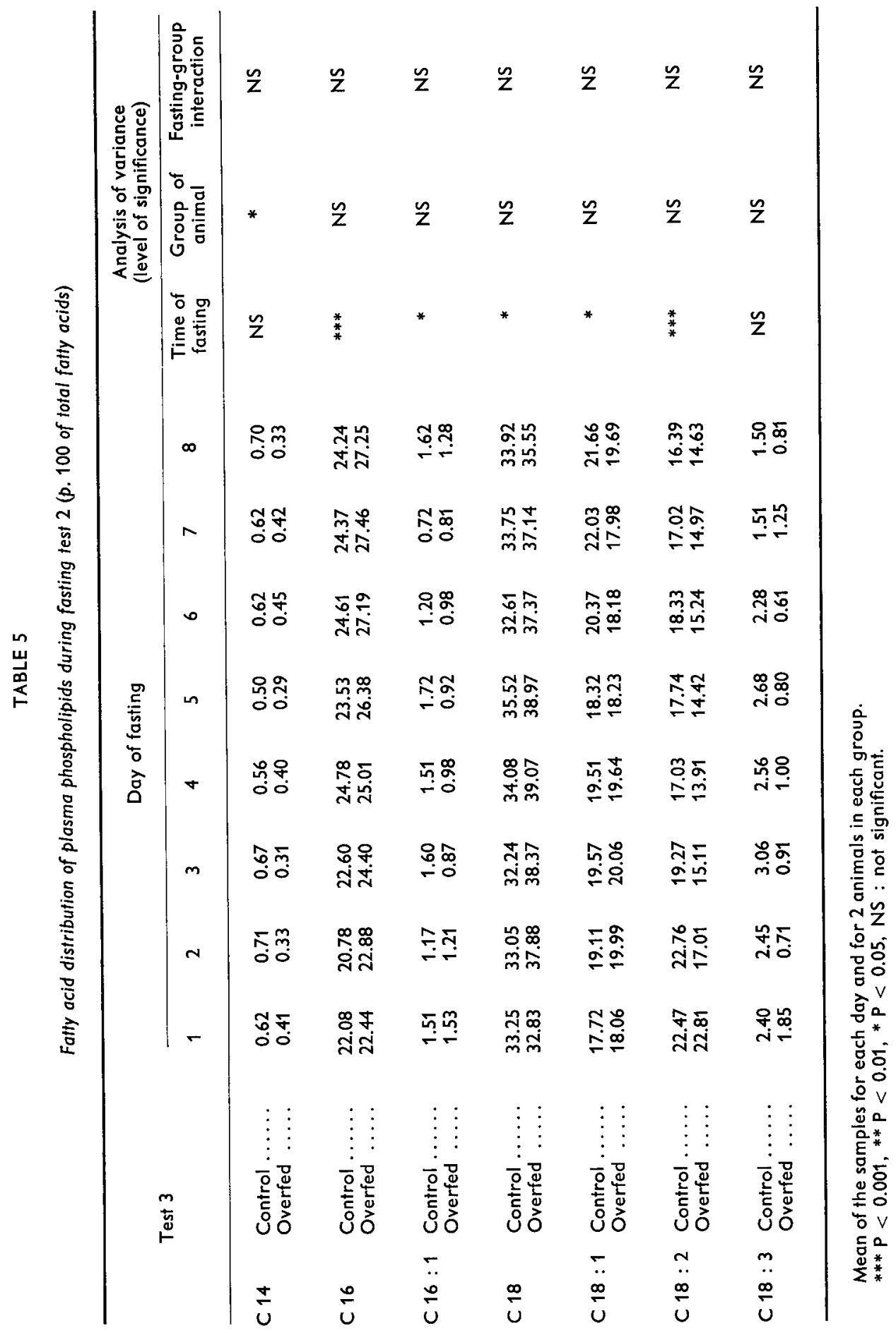




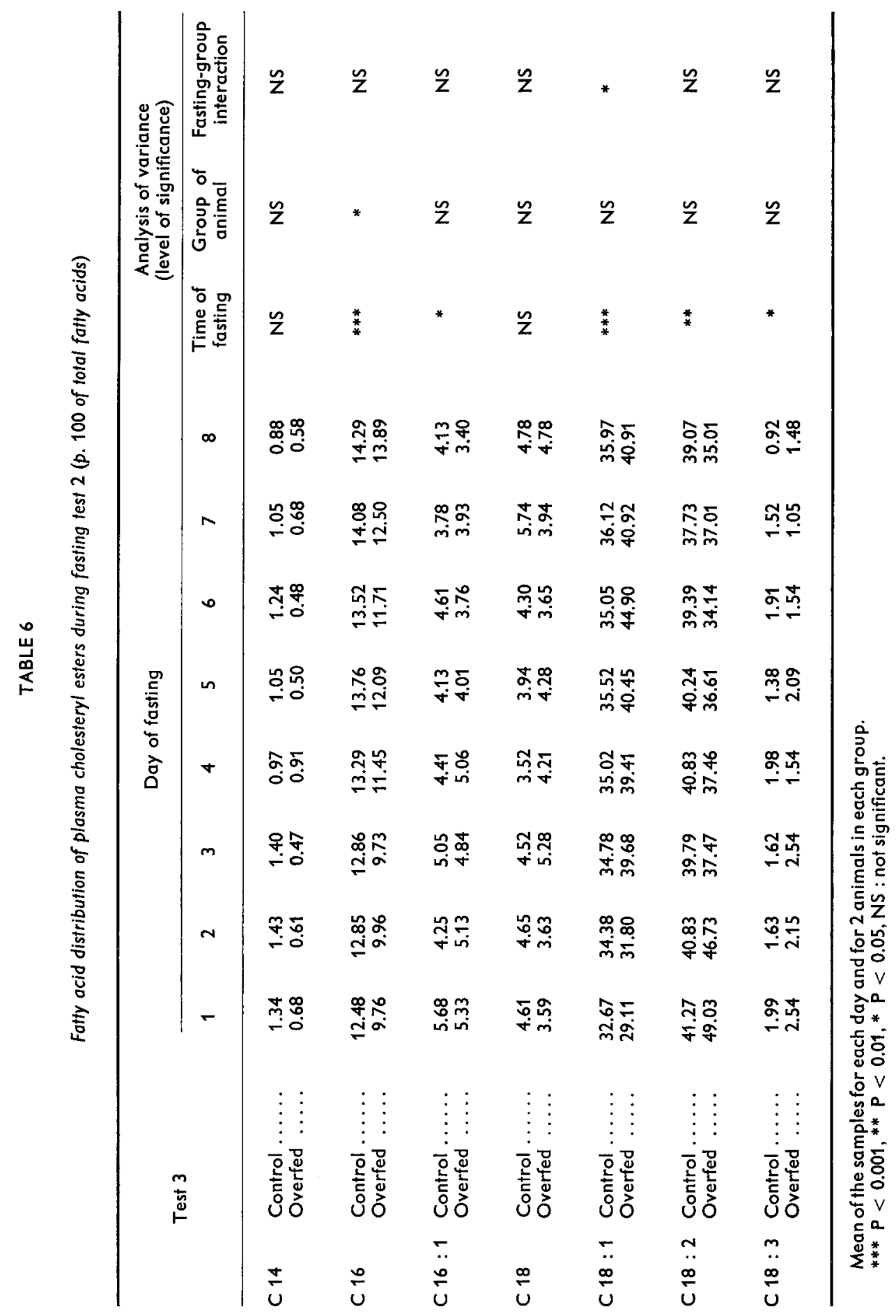




\section{Discussion.}

In ruminants, ketone bodies are not only synthesized from acetyl CoA in the liver, but also from volatile fatty acids (mainly butyrate) in the rumen wall (Goosen, 1976 ; Weigand, Young and Mc Gilliard, 1975) and, to a lesser extent, in the liver (Demigné and Rémésy, 1977). The first way leads to $A A$, and the second to $B H B$, with possible interconversions between these substances. One consequence is that the BHB/AA ratio in the blood is distinctly higher in ruminants (10 to 20 in feeding periods : Doizé, Bouchat and Paquay, 1979) than in simple-stomached animals (1 to 3 : Bates and Linn, 1976 ; Sicart, Sable-Amplis and Agid, 1978). A second consequence is that the ketone bodies have a more important metabolic function in ruminants, serving as a main energy source, especially in the brain (Kammula, 1976) and the kidneys (Kaufman and Bergman, 1971).

The first 24 hrs of fasting induced a decrease of ketone bodies in the blood, followed by a gradual increment starting 36 to $48 \mathrm{hrs}$ after food removal. Our results agree with those of Bowden (1973) and Münchow et al. (1976). The decrease in ketone boodies during the first day was a result of the last food allowance which induced a temporary increase in kelone production (Doizé, Bouchat and Paquay, 1979).

The $B H B / A A$ ratio remained stable during fasting in hamsters (Sicart, SableAmplis and Agid, 1978) and increased in rats (Bates and Linn, 1976). Our results demonstrated a decrease of this ratio (from 10 to 20 to 5 ) in sheep. This was obviously due to a reduction of $\mathrm{BHB}$ production from butyrate in the rumen wall and the liver (Annison et al., 1967 ; Katz and Bergman, 1969) and to a higher hepatic acetoacetate synthesis (Katz and Bergman, 1969). It was demonstrated in fasted cows that the liver stops taking up butyrate from the blood, but takes up more fatfy acids which are intensively translormed into ketone bodies (Baird ef al., 1977).

In cows, Bowden (1973) found no effect of the quantity of previously distributed food on the rate of the ketone bodies produced during fasting. Our tests showed that blood ketone level still increased in the underfed animals after 1 week of fasting, whereas it stabilized in the overfed sheep. Such a stabilization could be expected, since it has been demonstrated by Balasse and Neef (1975) and by Bates and Linn (1976) that when ketone bodies are produced in large amounts, they monitor their own synthesis, thus preventing anarchic hyperketonemia.

Since blood glucose level must be maintained within narrow limits, fasting does not influence glycemia as much as it does the concentration of ketone bodies. In sheep, Günzel and Giesecke (1974) observed no modification, Baetz (1976) and Demigné and Rémésy (1977) noted a limited decrease, and Bassett (1974) established an initial increase in the milk-fed lamb, followed by a decrease after 3 to $4 \mathrm{hrs}$. Such a profile is directly related to the last food allowance (Doizé, Bouchat and Paquay, 1979). Our results do not support any conclusion of an orderly pattern during the 8 days of fasting, although they seemed to show a decrease after 36 to $48 \mathrm{hrs}$ and an increase after 5 to 6 days.

It is not easy to maintain glycemia in ruminants at the physiological level during fasting due to the decrease of propionic acid absorbed from the rumen and transformed into glucose by the liver (Annison ef al., 1967 ; Katz and Bergman, 1969). The stabi- 
lity of glycemia is insured by the self-monitoring of the blood glucose. In cattle, an inverse relation has been observed between liver neoglucogenesis and external glucose supply (Thompson et al., 1975), and fasting elicits a reduction of glucose transport to the adipose cells and of glucose oxidation in those cells (Kasuga ef al., 1977 ; Olefsky, 1976). Steel and Leng (1973) noted a decrease of irreversible glucose losses in fasting sheep.

In addition, there is an obvious relation between glucose and ketone bodies in fasting. Demigné and Rémésy (1977) observed that an injection of glucose in fasted sheep decreased ketogenesis, thus proving that, even in ruminants, the high rate of ketone production after 1 to 2 days of fasting was necessary for supplying at least part of the required energy in order to avoid hypoglycemia.

From our results it cannot be determined whether or not dief before fasting had an effect on glycemia. Bowden (1973) arrived at the same conclusions.

In our conditions, fasting had little influence on the distribution of the blood lipids. Only a higher rate of cholesterol esterification was observed. Reid, Baird and Heitzman (1977) found a higher increase of cholesteryl esters than of cholesterol in the liver of fasting cows, whereas no modification of blood lipids was observed. Lee et al. (1977) noted no change in the ratio of esterified to unesterified cholesterol in the serum of fasting men.

As in other species, fasting induces an increase in the free fatty acid content in sheep plasma (Günzel and Giesecke, 1974 ; Thompson, Gardner and Bell, 1975 ; Thye, Warner and Miller, 1970). Our results confirmed this pattern and showed that the increment occurred at the end of the first day, and thus 12 to $24 \mathrm{hrs}$ before the increase of blood ketone bodies. The present results also agree with our previous finding (Doizé, Bouchat and Paquay, 1979) that there is no change during the day in the blood FFA content of fed sheep.

The concentration of plasma FFA, like that of the ketone bodies, tended to stabilize after 5 to 6 days of fasting. We concluded that the ketone bodies themselves regulated the rate of ketogenesis. The same conclusion can apparently be drawn for fatty acid mobilization, and there is an evident relation between this mobilization and ketogenesis. Thye, Warner and Miller (1970) demonstrated that the injection of $\beta$-hydroxybutyrate in lactating ewes induced a decrease of FFA concentration. Oleic acid infusions inhibited adipose tissue lipolysis and increased blood ketone concentration in intact fasted rats (Bates, Linn and Huen, 1976).

Our results showed that the prefast diet, hence the fattening state of the animal, had no effect on lipid distribution or on the mean level of FFA in the blood of sheep during fasting. Bowden (1973) noted no effect of the prefast feeding level on blood FFA concentration in cattle.

In our study, fasting induced some changes in the fatty acid distribution of blood lipids. An increased oleic acid rate was observed mainly in the FFA, but also in phospholipids and cholestryl esters. This was balanced by a decrease of saturated fatty acids (C 14, C 16, C 18) in the FFA and of the other unsaturated fatty acids (mainly linoleic acid, but also palmitoleic and linolenic acids) in the phospholipids and the cholesteryl esters. An increase of the palmitic acid rate was also noted in the last two lipid classes. It may thus be concluded that fasting induced a progressive impoverishment of the essential blood fatty acids in sheep. 
Leat and Ford (1966) noted an increase of stearic acid entering the plasma of starved, non-pregnant ewes, and of palmitic acid in pregnant ones. In the hamster, Sicart, Sable-Amplis and Agid (1978) observed a higher palmitic acid and a lower oleic acid content in the plasma during fasting, and Seerley and Poole (1974) suggested that prolonged fasting in swine induced a higher utilization rate of $C 18: 1$ from the energy reserves, whereas in other animal species $C 18: 2$ was more extensively used.

In the present study, the previous intake level, and thus the fattening state, affected the distribution and the profile of blood lipid fatty acids during fasting, but these results need confirmation.

The faecal nitrogen losses decreased rapidly during fasting (in the same way as the faecal dry matter), whereas urinary losses remained high for a few days, particularly in the overfed animals. In our experimental conditions, it was determined that during the first 4 days of fasting, the sheep lost 3 to 4 p. 100 of their total body protein. These results are confirmed by those on cattle (Biddle, Evans and Trout, 1975 ; Paquay, de Baere and Lousse, 1972), showing that body protein reserves include a labile fraction which is rapidly available when needed. In the rat, Millard ef al. (1974) observed that the abundant nitrogen losses were due to rapid catabolism of liver, muscle and heart protein and RNA.

Our results on blood ketone bodies, glucose and fatty acids and on urinary nitrogen losses during fasting showed that a close relation exists among these substances. Fasting disturbs the energy supply, which is then progressively assumed by the mobilization of the lipid reserves and by the increasing transformation of liberated fatty acids into ketone bodies. For certain organs (particularly the brain and kidneys), they are a better source of energy. But the mobilization of fat tissue and the increased production of ketone bodies need a few days to stabilize. The immediately available labile protein reserve seemed to be the intermediary supplying energetic substances and serving as a precursor of neoglucogenesis in order to avoid a drop in glycemia.

Recent observations support this hypothesis. The injection of $\mathrm{BHB}$ decreases the nitrogen losses in fasting humans (Sherwin, Hendler and Felic, 1975). The increase of protein catabolism in fasting mice favorized neoglucogenesis (Robinson et al., 1975). In fasting sheep, alanine has the same effect as glucose in decreasing ketogenesis (Demigné and Rémésy, 1977).

Reçu en mars 1979.

Accepté en juin 1979.

Acknowledgment. - This work was supported by the Institut pour l'Encouragement de la Recherche Scientifique dans I'Industrie et l'Agriculture (IRSIA), rue de Crayer, B-1050 Brussels, Belgium. The authors thank R. Hanset and C. Michqux of the Faculté de Médecine Vétérinaire, Brussels, for conducting the statistical analysis.

Résumé. En vue d'étudier l'évolution de la composition chimique du sang et des pertes azotées pendant une mise à jeun, des groupes de moutons adultes, préalablement soumis à des conditions alimentaires très variables, ont été privés de nourriture pendant des périodes de 8 jours.

Après une diminution initiale, la concentration en corps cétoniques du sang subit une forte augmentation à partir de la $36^{\mathrm{e}}$ ou $48^{\mathrm{e}}$ heure. Une stabilisation paraît se produire 
après 5 à 6 jours chez les animaux préalablement nourris à volonté, alors que l'augmentation se poursuit après une semaine chez les animaux préalablement nourris de manière limitée. Le rapport $\beta$-hydroxybutyrate/acetoacelate diminue.

Aucune évolution ordonnée n'est observée dans la glycémie si ce n'est peut-être une diminution après $36 \mathrm{~h}$ et une augmentation après 5 à 6 jours. Le niveau préalable d'alimentation n'a pas d'effet sur cette évolution.

La privation de nourriture induit une estérification plus grande du cholestérol sanguin et, à partir de la fin du premier jour, une rapide augmentation de la concentration en acides gras libres du sang suivie d'une stabilisation après 5 à 6 jours. La distribution des acides gras des fractions lipidiques du sang subit aussi diverses modifications. Il se produit notamment une augmentation de la proportion d'acide oléique aux dépens de celle des acides saturés dans les acides gras libres et des autres acides insaturés dans les phospholipides et les esters de cholestérol. Certaines de ces modifications dépendent des conditions préalables d'alimentation.

Les pertes azotées fécales diminuent rapidement pendant le jeône, alors que les pertes urinaires sont élevées les premiers jours, surtout chez les animaux préalablement suralimentés. 3 à 4 p. 100 des protéines corporelles totales sont perdus par ces animaux en 4 jours ce qui démontre l'existence d'une fraction labile, rapidement utilisable, dans les protéines de réserve.

Le rôle des corps cétoniques et des réserves protéiques dans la couverture des besoins énergétiques ef dans le maintien de la glycémie lors d'une privation de nourriture sont discutés.

\section{References}

ANNISON E. F., BROWN R. E., LENG R. A., LINDSAY D. B., WEST C. E., 1967. Rates of entry and oxidation of acetate, glucose, $\mathrm{D}(-)$ - $\beta$-hydroxybutyrate, palmitate, oleate and stearate and rates of production and oxidation of propionate and butyrate in fed and starved sheep. Biochem. J., 104, 135-147.

BAETZ A. L., 1976. The effect of fasting on blood constituants in domestic animals. Ann. Rech. véfér., 7, 105-108.

BAIRD G. D., REID I. M., LOMAX M. A., SYMONDS H. W., ROBERTS C. J., MATHER D., 1977. Hepatic glucogenesis and fat metabolism in fed and fasted lactating dairy cows in vivo. Proc. Nufr. Soc., 36, 40A.

BALASSE E. O., NEEF M. A., 1975. Inhibition of ketogenesis by ketone bodies in fasting humans. Metabolism, 24, 999-1007.

BASSETT J. M., 1974. Early changes in plasma insulin and growth hormone levels after feeding in lambs and adult sheep. Aust. J. biol. Sci., 27, 157-166.

BATES M. W., LINN L. C., 1976. Blood D-3-hydroxybutyrate and the regulation of plasma concentrations of free fatty acids in the fasted rat. Metabolism., 25, 685-695.

BATES M. W., LINN L. C., HUEN A. H. J., 1976. Effects of oleic acid infusion on plasma FFA and blood ketone bodies in the fasting rat. Metabolism, 25, 361-373.

BIDDLE G. N., EVANS J. L., TROUT J. R., 1975. Labile nitrogen reserves and plasma nitrogen fractions in grazing cattle. J. Nutr., 105, 1584-1591.

BOWDEN D. M., 1973. Effects of postfeeding interval on blood constituants related to energy metabolism in non pregnant Angus and Hereford heifers. Can. J. Anim. Sci., 53, 641-646.

DEMIGNÉ G., RÉMESY C., 1977. Ketogenesis in the fasting ruminant. Effect of volatile fatty acids, glucose and alanine. Ann. Biol. anim. Bioch. Biophys., 17, 887-895.

DOIZÉ F., BOUCHAT J. C., PAQUAY R., 1979. Diurnal changes in blood ketone bodies, glucose and lipids according to energy intake in the adult sheep. Ann. Biol. anim. Bioch. Biophys., 19, $393-$ 404.

GOOSEN P. C. M., 1976. Metabolism in rumen epithelium oxidation of substrates and formation of ketone bodies by pieces of rumen epithelium. Z. Tierphysiol., Tierernährg. Futtermittelkde, 37, 14-25. 
GÜNZEL R., GIESECKE D., 1974. The influence of feeding, fasting and phloridzin diabetes on the relationship between free fatty acids and glucose in the blood of sheep. Zbl. Vet. Med. A, 21, 279-284.

KAMMULA J. G., 1976. Metabolism of ketone bodies by ovine brain in vivo. Am. J. Phys., 231, 1490-1494.

KASUGA M., AKANUMA Y., IWAMOTO Y., KOSAKA K., 1977. Effect of fasting and refeeding on insulin receptors and glucose metabolism in rat adipocytes. Endocrinology, 100, 1384.

KATZ M. L., BERGMAN E. N., 1969. Hepatic and portal metabolism of glucose, free fatty acids, and ketone bodies in the sheep. Am. J. Physiol., 216, 953-960.

KAUFMAN C. F., BERGMAN E. N., 1971. Renal glucose, free fatty acid, and ketone body metabolism in the unanesthetized sheep. Am. J. Physiol., 221, 967-972.

LEAT W. M. F., FORD E. J. H., 1966. Utilization of free fatty acids by starved and pregnant sheep. Biochem. J., 101, 317-322.

LEE P. A., WALLIN J. D., KAPLOWITZ N., BURKHARTSMEIER G. L., KANE J. P., LEWIS S. B., 1977. Endocrine and metabolic alterations with food and water deprivation. Am. J. clin. Nutr., 30, 1953-1962.

MILLARD D. J., NNANYELUGO D. O., JAMES W. P. T., GARLICK P. J., 1974. Protein metabolism in skeletal muscle : the effect of feeding and fasting on muscle RNA, free amino acids and plasma insulin concentrations. Br. J. Nutr., 32, 127-142.

MÜNCHOW H., SCHÜLKE B., DARGEL D., BERGNER H., ROSSOW N., 1976. Variations in the pattern of ruminal volatile fatty acids and in the levels of free fatty acids, acetoacetate and glucose in the blood plasma of lactating cows after a period of fasting and renewed food supply. Arch. Tierernährung, 7, 533-540.

OLEFSKY J. M., 1976. Effects of fasting on insulin binding, glucose transport and glucose oxidation in isolated rat adipocytes. J. clin. Invest., 58, 1450-1460.

PAQUAY R., DE BAERE R., LOUSSE A., 1972. The capacity of the mature cow to lose and recover nitrogen and the significance of protein reserves. Br. J. Nutr., 27, 27-37.

REID I. M., BAIRD G. D., HEITZMAN R. J., 1977. Effects of fasting in non lactating cows. A correlated biochemical and stereological study of fasting-induced fatty liver. J. agric. Sci., 89, 319-325.

ROBINSON D. W., HODGSON D., BRADFORD G. E., ROBB J., PETERSON D. W., 1975. Effects of dietary restriction and fasting on the body composition of normal and genetically obese mice. J. Anim. Sci., 40, 1058-1062.

SEERLEY R. W., POOLE D. R., 1974. Effect of prolonged fasting on carcass composition and blood fatty acids and glucose in neonatal swine. J. Nutr., 104, 210-217.

SHERWIN R. S., HENDLER R. G., FELIG P., 1975. Effect of ketone infusions on amino acid and nitrogen metabolism in man. J. clin. Invest., 55, 1382-1390.

SICART R., SABLE-AMPLIS R., AGID R., 1978. Changes in lipid metabolism induced by starvation and cold exposure in the golden hamster. Comp. Biochem. Physiol., 59A, 335-338.

STEEL J. W., LENG R. A., 1973. Effects of plane of nutrition and pregnancy on gluconeogenesis in sheep. Br. J. Nutr., 30, 451-473.

THOMPSON G. E., GARDNER J. W., BELL A. W., 1975. The oxygen consumption, fatty acid and glycerol uptake of the liver in fed and fasted sheep during cold exposure. Quart. J. exp. Physiol., 60, 107-121.

THOMPSON G. E., MANSON W., CLARKE P. L., BELL A. W., 1978. Acute cold exposure and the metabolism of glucose and some of its precursors in the liver of the fed and fasted sheep. Quart. J. exp. Physiol., 63, 189-199.

THYE F. W., WARNER R. G., MILLER P. D., 1970. Relationship of various blood metabolites to voluntary feed intake in lactating ewes. J. Nutr., 100, 565-572.

WEIGAND E., YOUNG J. W., Mc GILLIARD A. D., 1975. Volatile fatty acid metabolism by rumen mucosa from cattle fed hay or grain. J. Dairy Sci., 58, 1294-1300.

YOUNG J. W., 1977. Glucogenesis in cattle : significance and methodology. J. Dairy Sci., 60, 1-15. 